\title{
PLEDOARIE PENTRU WILSON. PREȘEDINTELE WILSON - SOL AL LIBERTĂȚII POPOARELOR OPRIMATE DIN EUROPA DE EST
}

\author{
Prof.univ.dr. Mircea Popa
}

Intrând în anul Centenarului Marii Uniri, numele președintelui american Woodrow Wilson (1852-1924) urmează să fie tot mai des invocat, întrucât vizunea sa asupra noii configuraţii europene a fost cu bucurie îmbrățișată de toate popoarele asuprite din centrul și sud-estul european, ducând la un proces salutar de cucerire a libertății şi independeței naționale a acestora. $\mathrm{Cu}$ alte cuvinte, numele președintelui american este legat organic de acel fenomen istoric de formare a statelor naționale, care până atunci au fost impedecate de a-și lua destinul în propriile mâini. Datorită intervenției sale în spațiul public, prin darea la iveală a celor 14 puncte devenite celebre, construcția statală europeană a cunoscut o nouă reașezare. A fost președintele american care, odată cu intrarea Statelor Unite în Primul Război Mondial, a încercat să dea şi o turnură de democrație finalităţii lui, oferind o şansă primordială popoarelor central și est-europene (cehi, slovaci, polonezi, români, sârbi, croați, baltici etc.), care până atunci n-au putut să-și creeze state naționale, dat fiind că au intrat în componența unor imperii asupritoare. Cele 14 puncte ale actului său de conduită, făcute publice în camerele reunite ale Congresului american la 8 ianuarie 1918, au devenit un fel de Biblie a popoarelor, o chezăşie pentru constituirea de state naționale pe ruinele imperiului austro-ungar, aflat în plin proces de disoluție. În mod paradoxal chiar și ungurii, asupritori pentru o parte din aceste popoare, au beneficiat de acest principiu călăuzitor, întrucât pacea finală, prin tratatul de la Trianon, le-a oferit posibilitatea de a-și crea un stat naţional în marginile teritoriului național și al frontierelor demografice în care erau așezați. Au stat când sub turci (sub forma unui rușinos pașalâc după 1526), când sub austrieci, iar încercarea lor absolut condamnabilă de a maghiariza cu forța națiunile trans-leithane le-a adus calificarea de ,cel mai reacționar stat european de la acea dată" (Scotus Viator). Principiile wilsoniene au fost îmbrățișate cu ardoare de popoarele europene care își doreau forme statale proprii, mai ales că au fost însoțite de unele adrese directe către cei care jinduiau la libertate, inclusiv către români. În urma primirii lui Vasile Lucaciu la Casa Albă și a memoriilor adresate de românii americani, președintele Wilson și secretarul său de stat Robert Lansing au exprimat un punct de vedere indubitabil în favoarea românilor transilvăneni. La Cleveland, în 1918, s-a creat „Liga Națională Romînă din America, ” în frunte cu un Comitet din care făceau parte Vasile Stoica, Vasile Lucaciu și fiul său Epaminonda Lucaciu, organizație care au organizat numeroase întruniri și manifestaţii pentru cauza românească, ducând $\mathrm{o}$ propagandă activă în spațiul american în favoarea tratativelor de pace ropuse de președintele american. Marele război european, vinovat de moartea atâtor vieți în cursul a patru ani de confruntări neîntrerupte, trebuia să asigure, în opinia sa, cadrul cel mai potrivit pentru o pace durabilă, prin eliminarea totală a disputelor teritoriale şi a ambițiilor ilegitime ale unor agresori improvizați, prin punerea pe primul loc a principiilor libertății, independenței și autonomiei acestora în raport cu imperiile care le-a asuprit. Prin vocea președintelui american s-a auzit răspicat în lume principiile călăuzitoare ale celei mai înaintate democrații mondiale. America n-a intrat în război pentru că ar fi avut ceva cu Germania, cu Austria sau 
cu Ungaria, principalele promotoare ale alianței Puterilor Centrale. Statele Unite au intrat în război, pentru a corecta în Europa ceea ce de mult timp a fost considerat anacronic, revolut, depăşit, expirat, adică pentru a sprijini efortul democratic de nouă așezare a Europei pe alte baze, așa cum o pretindeau principiile înaintate ale secolului al XX-lea. Secolul acesta a fost numit în consecință „secolul națiunilor”, și a dus la o nouă configurație statală a bătrânului continent. Austria a fost cel dintâi stat care a înţeles sensul mesajului wilsonian și ca atare, după moartea bătrânului și anchilozatului Franz Iosif, urmaul său arhiducele Carol a dat un masaj către toate popoarele și națiunile din imperiu acodându-le libertatea deplină în ceea ce privește viitoarea lor opțiune statală. A fost un act logic și previzibil căruia i-au alăturat toate popoarele care au făcut anterior parte din acest conglomerat statal hibrid, cu excepția maghiarilor care își manifestau intenţia de a păstra în cadrele țării lor, vechiul principat autonom al Transilvaniei, păstrând, evident, acea hegemonie condamnabilă pe baza căreia introduseseră politica de maghiarizare forțată. Punctele programului wilsonian au creat cadrul potrivit în care cele mai multe națiuni au ales drumul formării de state independente. Doar maghiarii, aşa cum am arătat, s-au arătat a fi sceptici, încercâd să perpetueze perpetueze vechile realităţi arhifeudale existente. În disperare de cauză, ei au apelat la două subterfugii condamnabile. Cea dintâi opțiune încerca să perpetueze dualismul prin alegerea arhiducelui Iosif, ca un potențial simbol habsburgic tradiţional, în vederea păstrării unui stat național cu infuzie austriacă. Cea de a doua opțiune, găsită în situația de criză și degringoladă în care intrase administrația statală, s-a dovedt a fi și mai nefericită. Prin ea, ultimii politicieni maghiari rămaşi la cârmă în etapa ultimelor zvîrcoliri dinainte expierii definitive, au apelat ca la o ultimă amăgire: aceea de a încredința puterea politică revoluționarului de carton, fostului parlamentar socialist Bela Kun, în ideea că bolşevicul roșu din Petrogradul revoluționar, Lenin, i-ar putea pune la dispoziție trupe cu care să invadeze Transilvania, spre a o păstra în chingile unei opresiuni autarhice. Această opțiune, căreia i-a dat credit și premierul Karolyi, interesat să-și păstreze moșiile și castelul din zona Careiului, s-a dovedit o alternativă falimentară, deoarece trupele secuilor, care au pornit să bage groază în românii din Transilvania prin jafuri și crime abominabile, şi-au dovedit în curând ineficiența în fața armatei române atotbiruitoare.

Intervenția în spațiul european al președintelui Statelor Unite a fost de la început salutară. Punctele formulate de el au avut manirea să înlăture arbitrariul și pretențiile de dominație ale unor popoare cu ambiții nefondate, care doreau perpetuarea vechiului statu-quou, rezultat din cuceriri și asuprire generalizată, în timp ce formulările wilsoniene reclamau un alt mod de abordare a colaborării dintre națiuni, bazat pe respect reciproc, conviețuitre pașnică și egalitatea de şanse.Tipul de stat imperialist, cu regim despotic, fundamentat pe asupriri, condamnări, închisori, lagăre, tabere de muncă, colonizări era total dezavuat. A fost și cazul poporului român din Transilvania, care, mai ales în anii războiului, a trăit un coșmar continuu, în condițiile unei adevărate stări de asediu, irespirabile. Mii de familii au luat drumul țării libere de dincolo de munți; în timp ce celor rămași li s-a impus condiții cu totul infernale, fiind târâți în lagăre, închisori, tabere de muncă, în timp ce gospodăriile lor au fost călcate, incendiate, distruse, făcând loc unor colonizări abuzive. „După un an de război, - scria O.Goga în articolul său Unirea tuturor românilor -, în toamna anului 1915, în satele românești nu se mai găseau decât bătrâni de peste 60 de ani, femei și copii. Toți ceilalți erau pe câmpul de bătaie, parte ca combatanți, parte ca muncitori la tranșee. Între cei de acasă stăpânea teroarea jandarmilor și a spionilor fără număr. Familiile celor care trecuseră munţii pentru a se înrola în armata română erau prigonite, iar ei înșiși declarați trădători și averea lor se vindea la licitaţie." În plus, regimentele românești erau întotdeauna trimise în prima 
linie, acolo unde moartea era asigurată. În aceste condiții, principiile wilsoniene au venit ca un baslam peste rană pentru toate națiunile aflate sub cnutul maghiar, cunoscut pentru intenția lui nebunească de a maghiariza pe toți nemaghiarii. Lichidarea școlilor, suprimarea presei, arestările masive, judecăţile superficiale, condamnările la moarte, au dat acestui „draconism turanic”, cum a fost caracterizat, aspectul celui mai opresiv regim din Europa. Reprezentanții națiunii române au dat publicităţii Declarația de la Oradea, urmată de manifestul Către popoarele lumii, în care se salutau principiile wilsoniene, evocate cu apăsată subliniere de vorbitorul Ştefan Cicio-Pop în cuvântarea sa. Iată formularea: „Momente senine apărură pentru neamul românesc atunci când se amestecară în război Statele Unite nord-americane și când marele Wilson, al doilea Mesia, face legi pentru popoarele lumii." La rândul său, președintele PNR, Gheorghe Pop de Băsești, declara la aceeași adunare de la Alba Iulia: „După dezrobirea noastră din iobăgie a urmat altă iobăgie și mai mare, iobăgia sufletelor noastre, iar apoi a urmat iobăgia de clasă. Astfel, onorată adunare, la locul acesta sfinţit de sângele marilor noștri martiri, v-ați adunat dumneavoastră ca să sfărâmați și cătușele robiei noastre spirituale, ale robiei noastre seculare şi să decidem, ca un popor liber, asupra sorții noastre, precum ne-a trimis solia marele Wilson, care a fost cel dintâi, care a înțeles cum că sfintele învățături ale lui Isus Cristos, cum trebuie să se aplice între popoare." Și Vasile Goldiş, în raportul său de la Alba Iulia, a adus în discuție ideile libertăţii, progresului și independenței popoarelor, trimițând în chip direct la sursa primară: „Ideile acestea le-a copt istoria şi apostolul care le vestește este Wilson.”

Toate aceste frumoase epitete caracterizante, care îl aseamănau pe W.Wilson cu Mesia, sau cu ,apostolul dezrobirii noastre”, au făcut din președintele Wilson un crainic al libertăţii popoarelor, faima sa pătrunzând în chip semnificativ în întreg arealul central şi sud-european, printr-o campanie de presă ridicată la cele mai înalte cote. Aproape n-a fost publicaţie cât de cât importantă care să nu fi făcut referiri la salutarele intervenții wilsoniene de a restructura sistemul de putere european, de a-l așeza pe cele mai moderne baze. Vom încerca în cele ce urmează să oferim un mic florilegiu din mulțimea articolelor de presă care i-au fost închinate, spre a ne face o imagine cât mai aproape de adevăr despre modul în care aceste puncte wilsoniene au constituit motorul efortului material şi spiritual al fostelor popoare asuprite în încercarea lor de desprindere de trecutul tenebros. Vom fi călăuziţi în această întreprindere de lucrarea lui Charles Zorgbibe, Wilson. Un cruciat la Casa Albă (ed. Fundaţia Europeană Titulescu, București, 2003, trad. din lb. franceză de Daniela Borceanu). Ales ca președinte pe listele Partidului Democrat în alegerile din 1912, profesorul de la Princeton, Woodrow Wilson, a fost un vizionar care nu s-a mărginit doar a da națiunii sale o serie de legi democratice, ci s-a implicat cu magnimică adrență la schimbări și sugestii care priveau situaţia globală a stării politice a neamurilor. Mai întâi a considerat că e cazul să ajute Europa spre a-și implementa principiile democratice de guvernare, propunând totodată să se renunțe la confruntările militariste, soldate cu măcelărirea unor mari mase de oameni, cu distrugeri masive de bunuri materiale și spirituale, cu eludarea drepturile omului și cu introducerea arbirariului și inegalității. A propus, în consecință, beligeranților să treacă într-n timp cât mai scurt la tratative de pace, pentru a pune capăt acestui istovitor carnagiu. Așa, de pildă, ziarul „Unirea” din Blaj publica în nr. 4 din 1917 Adresa lui Wilson către Senat în chestia păcii, atrticol comentat și în „Gazeta Transilvaniei” în nr. 6/1917 din 17/30 ianuarie 1917. Ziarul blăjean relua problema în nr.5/191, pe tema În jurul aporturilor de pace ale lui Wilson, ocazie $\mathrm{cu}$ care erau luate în discuție principiile pentru formarea de noi state naţionale. Intervențiile publice ale președintelui american au fost repede receptate și comentate și de către presa 
română. Este și cazul ziarului „Izbânda” de la Iași, care se număra printre puținele organe de presă ce mai apăreau în cursul anului 1918, și care comenta aproape număr de număr fiecare nouă intervenție și declarație a președintrelui american. Interesul cu care acest ziar urmărește prestația gândirii ideologice a președintelui american este de-a dreptul impresionantă, subliniindu-se cu salutară bucurie insistenţa acestuia asupra unor probleme capitale pentru situația din Europa, deoarece Statele Unite au simţot de la început datoria ,în nădejdea mare şi onorabilă ca aceea în toată ființa și faptele i să arate omenimii calea spre libertate." În scrisoarea adresată senatului american, președintele Wilson se simte dator să itinereze obligația democrației americane de a ajuta peste tot în lume la progresul general. Acest lucru se face $\mathrm{cu}$ un interes sporit, deoarece președintele american are capacitatea de a se adresa în intervențiile sale în mod particular pe rând principalelor țări participante la război, cum ar fi Germania și Austro-Ungaria. Iată, de pildă, câteva dintre aceste texte comentate de „Gazeta poporului" de la Sibiu, cum ar fi Cuvântul de laudă al lui Wilson (nr.22/1918), O nouă vorbire a lui Wilson (nr.24/1918), Cuvântul lui Wilson către francezi (nr.n24), De vorbă cu Wilson despre pace. Ce a răspuns Wilson Austro-Ungariei (nr.43/1918), Wilson și românii (nr. 44/1918) etc., Cum mângîie Wilson pe ruși (nr. 11/1918).

In set de idei dintre cele mai înaintate poate fi descifrat în Solia lui Wilson către Senat, publicată și comentată în „Gazeta Transilvaiei" din februarie 1918. Acolo Wilson reitera câteva din principiile pe care să se întemeieze viitoarea constructie europeană. Cel dintâi dintre acestea privea egalitatea dintre state, asupra căreia stăruie de mai multe ori: „Egalitatea națiunilor, pe care trebuie intemeiată pacea, dacă dorim să fie durabilă, trebuie să fie o egalitate de drepturi." Și mai departe: „O pace care nu recunoaște și nu acceptă acest principiu, va fi necondiționat răsturnată. $\quad \mathrm{Ea}$ nu va fi întemeiată pe înclinațiunile ori pe convingerile omenimei. Fermentul spiritului popoarelor întregi va fi îndreptat contra ei. " Egalitatea de drepturi el o corelează cu libertatea de mișcare, deoarece „nicio națiune nu trebuie să fie ținută departe de accesul liber la căile deschise ale comerțului lumesc." O altă condiție a libertății națiunilor trebuie să izvorască din discuția liberă și sinceră dintre statele vecine și partenerii de afaceri, pe motiv că „legătura neîntreruptă între popor și popor este o parte esențială a păcii și a procesului de dezvoltare." Promovarea egalității dintre popoare trebuie să ducă la alianțe corecte, pe baze de respect reciproc, deoarece ,într-un sistem de puteri nu există alianțe încurcate". Toate aceste principii izvorăsc din statutul de independendenţă şi libertate al popoarelor, căci ,și cel mic și cel mare are voie liberă a-și determina însuşi forma de guvernământ și mersul său de dezvoltare neîmpiedecat, neamenințat și neînfricat." Sunt norme de existență de o valoare teoretică şi practică dea dreptul revoluționare.

Acest set de principii au făcut o bună impresie gânditorilor înaintați din Europa și în au reprezentat o adevărată gură de oxigen pentru fostele popoare asuprite care tocmai atunci căutau căile cele mai propice pentru eliberare și organizare, unele dintre ele fiind prinse încă în conflagrația mondială. Dândusi seama de valoarea acestor norme directoare, Wilson a revenit în curând asupra propunerilor sale pentru conducătorii statelor europene și le-a dat o sinteză fericită într-un număr de 14 puncte cu valoare orientativă, pe care le face cunoscute pe căile presei în toate statele lumii, unde vor fi copios comentate și discutate. Potrivit viziunii sale lumea ar trebui să intre într-o nouă etapă de abordare și de definire a relațiilor reciproce, înlăturând pe cât posibil confruntările armate spre a le înlocui cu tratate și cu înțelegeri reciproce, introducând cu precădere o etapă a păcii, conlucrării și progresului, sugerând chiar o reducere și un control al înarmărilor. 
Înțelegerile nu mai trebuie să fie secrete, ascunse, acoperind „lipsa de onestitate” și ascunzișurile dubioase. În acest scop trebuia pornit de la câteva principii generale care să asigure libertatea absolută a navigației pe mări, fiecare țară restrângându-și autoritatea doar asupra apelor teritoriale. Ca un corolar al circulație libere pe mările și oceanelor lumii trebuie să funcționeze și un sistem mai liber de condiţii comerciale şi de bariere economice, care să permită un flux cât mai mobil al schimburilor de mărfuri dintre state. Deshiderea spre colaborare trebuia să fie urmată și de o etapă de reducere a armamentelor ,,până la nivelul minim necesar menţinerii securității interne”, astfel că preocuparea statelor să nu fie aceea orientată spre expansiune teritorială, ci spre exploatarea propriilor resurse ale subsolului, lucru care ar duce la o dezvoltare intensivă și nu expansivă. În acest sens el recomandă chiar o revizuire a stadiului ocupărilor coloniale, care să aibă în vedre și ,interesul populațiior cât și justețea revendicărilor”. Dacă primele 5 puncte aveau un caracter general, vizând un ansamblu de măsuri în care puteau fi regăsite interesele întregii comunităţi de state, începând cu punctul 6, el va introduce o serie de prevederi cu trimitere la aspecte punctuale ale stării particulare ale principalelor state aflate încă în situația de război, astfel ca la masa păcii se se facă cât mai mare dreptate. O primă aserțiune se referea la Rusia și la schimbările prin care a trecut aceasta, țară care trebuia scoasă de sub regimul cazon de ,jandarm al popoarelor”, dar și de sub domnia bolșvismului, cu recomandarea ca problemele globale ale țărilor europene să rămână în atenția Societății Naţiunilor, ,garantând poporului rus libera determinare și alegere a propriilor instituții”. Urma la rând Belgia, stat care trebuia recunoscut şi lăsat să se manifeste prin „restituirea tuturor drepturilor sale”. În mod neîndoios Franța era privită şi judecată prin prisma pierderilor sale teritoriale din timpul războiului cu Germania din 1870, prevăzând la punctul 8 , o recomandare la reintrare în normalitate și o reîntregire a teritoriilor pierdute la 1870-1871, respectiv a Alsaciei și Lorenei ,pierderi care au rănit pacea lumii timp de aproape cincizeci de ani.” Și pentru Italia, țară de curând unificată, Wilson are un cuvânt greu de spus, cerând ,rectificarea frontierelor sale în lumina drepturilor acestei țări” (punctul 9). La punctul 1o se avea în vedere situația Austro-Ungariei, căreia i se recomanda ferm să asigure „dezvoltării autonome a popoarelor", care să fie primite cu drepturi egale ,în concertul naţiunilor”, ceea ce însemna de fapt disoluția ei. La punctul 11 se făcea aluzie și la țara noastră, așa că voi reproduce în întregime formularea sa: „Retragerea / armatelor austro-ungare -n.n./ din România, Serbia și Muntenegru, acestea urmând să reintre în posesia teritoriilor eliberate (...), respectarea independenței politice și economice, precum și a integrităţii teritoriale a popoarelor balcanice, $\mathrm{cu}$ care trebuie să se dezvolte relații de prietenie, potrivit principiilor naționalității stabilite de istorie." Prin acest punct, Wilson voia să sugereze nevoia încetării războiului din zonă, retragerea dominației habsburgice, spre a lăsa curs liber pentru dezvoltarea independentă și suverană a statelor, înlocuind politica de cucerire şi de expansiune cu ,relații de prietenie", asigurând pentru toate popoarele din fosta sferă austriacă posibilităţi proprii de dezvoltare și de prosperare. Următorul punct privea Turcia, care trebuia să asigure statutul de liberă trecere prin Dardanele, statut care să fie garantat de forţe internaţionale, recomandând să-și restrângă pretențiile la propriile hotare, în așa fel ca să permită „dezvoltarea autonomă a principiilor care nu sunt turcești”. Următorul punct, 13 privea formarea statului polonez, care trebuia să fie lăsat să se manifeste liber în ,teritoriile locuite", asigurându-i-se totodată și acces la mare, dar și „independența sa politică și economic, precum și integritatea teritorială”. Era o prevedere absolut meritorie, căci statul polonez fusese în mai multe rânduri desfințat și împărțit între puteri europene expan- 
sioniste, care trebuiau să-și restrângă preocupările doar la propriile teritorii. Punctul ultim prevedea, așa cum era și firesc, și anumite garanții că aceste schimbări nu vor fi anulate, ci vor avea asigurate pe viitor dezvoltarea lor firească. Garanţia acestora trebuia să fie fundamentată pe ,constituirea unei asociații a națiunilor”, lucru care s-a și întâmplat prin înființarea Societatății Naţiunilor, unde România a jucat un rol însemnat prin Nicolae Titulescu, considerat un mare jurist al veacului.

Cele 14 puncte diriguitoare ale lui Wilson au fost foarte bine primate de români, fiind reproduce și comentate favorabil de toate ziarele timpului. Excepție de la acestă poziție a făcut „Gazeta Trnasilvaniei”, încăpută în acel moment pe mâna unui gazetar trădător, Arseniu Vlaicu, cel care a condus ani de zile ziarul filomaghiar „Deșteptarea”. Foia braşoveană ajunsese prin intermediul lui o simplă fițuică aservită guvernului Tisza și a acolitului acestuia, mitropolitul Mangra, care au acuzat acolo atât participarea României la alianța cu Antanta (vezi articolul lui Vasile Mangra, Antanta-pacostea românis-mului, nr.29/1917), cât și linia politică GogaLucaciu, acuzată că ,ea nu reprezenta poporul românesc din Ungaria, nu exprimă sentimentele și convingerile poporului nostru, nu întrupează idealul Ardealului”, nr. 10/1917). În rest, întreaga presă românească a făcut propunerilor wilsoniene o mare popularitate, subliniind caracterul lor progresist, înaintat. Era vorba de a lansa în spațiul public noi norme de conviețuire dintre state, cu referiri la o adevărată doctrină a păcii și războiului, la o știință a tratatelor, a introducerii unui alt mod de rezolvare al conflictelor dintre satate. Unul dintre tinerii jurnaliști de atunci, Radu Dragnea, saluta în revista „Luceafărul” din 1919 ideile Wilsoniene ca e o „ideologie” a noului, ca pe un corolar al libertății. Era prin urmare firesc, ca toate actele emanate în sistemul public de fruntașii politici ai românilor, ardeleni în primul rând, să se bazeze pe noua concepție wilsoniană despre pace și război, despre granițe și principiile naționalității.

Odată ce a fãcut publice cele 14 puncte ale sale, oamenii politici români au primit noi încurajări în lupta lor pentru susținerea cauzei românești. Majoritatea documentelor de presă care apar nu mai pot face abstracție de punctele de vedere wilsoniene, întrucât ele furnizau argumente dintre cele mai peremptorii pentru etapele care trebuie urmate de către fiecare popor în parte în drumul lor spre câștigarea libertății, independenței și autonomiei teritoriale. Membrii Comitetului executiv al PNR, întruniţi la Oradea la 12 octombrie 1918, în comunicatul pe care îl dă publicității „Gazeta poporului” afirma că oamenii politici întruniți acolo ,au cercetat cu de-amănuntul situaţia și mersul lucrurilor, în urma ofertului de pace făcut de monarhia noastră către Wilson, pe temeiul celor 14 puncte cunoscute" a luat măsura ca deputatul Al.Vaida Voevod să anunțe în parlamentul din Budapesta hotărârea ca românii să se retragă din acest organism, întrucît nu-i mai reprezintă. Punctele de vedere ale lui Wilson fac apoi obiectul unei noi abordări de către Vasile Goldiș în cadrul interviului pe care i-1 solicită unul dintre redactorii ziarului „Aradi Hirlap”. La întrebarea acestuia că despre români nu s-ar face trimitere directă în aceste puncte, Vasile Goldiș ripostează cu o lămurire cât se poate de firească: „La această întrebare este un singur răspuns. Wilson nu se referă la români din aceleaşi motive pentru care nu face mențiuni despre poloni și italieni. Fiecare om lucid va înțelege adevărul. Numai cei cu gânduri infantile mai pot crede, când noua concepție despre lume asigură pentru toate popoarele monarhiei dreptul de autodeterminare că în cazul românilor se va face excepțiee, urmând ca aceștia și pe mai departe să fie lăsaţi sub pretinsa grijă paternă a patrioților de ocazie. Discursurile și scrierile lui Wilson numai aceia nu le înțeleg, care se gândesc în mod obscur. Răspunsul de acum al președintelui este absolut clar. Președintele nu mai este în situația să recunoască ca bază a 
păcii numai pura autonomie a popoarelor, el este nevoit a avea în vedere că popoarele înşile trebuie să decidă asupra soartei lor. Aceasta este sancționarea necondiţionată a dreptului la autodetermiare. Președintele Wilson într-adevăr s-a abătut de la cele 14 punct din 8 ianuarie, dar o astfel de declarație nu se face pentru prima dată. În răspunsul dat monarhiei și în discursul său adresat congresului se găsește următorul pasaj: „Rădăcina acestui război rezidă în lipsa de drepturi a națiunilor şi raselor mici, în care lipsește unitatea și puterea ca să realizeze cerinţele lor în problema apartenenței lor statale și în privința organizării independenței, a vieții lor politice.” La fel, în acest discurs a declarat Wilson că ,asemenea probleme teritoriale, pe care le-a ridicat războiul, trebuiesc rezolvate în interesul și în favoarea populației respective.” Desigur că aceste declarații se referă nu numai la cele 2 milioane de slovaci, sau 1, 8 miloane de croaţi, ci se referă și la cele 3, 5 miloane de români." (Apud Aexadru Roz, Consiliul Naţional Român Central și gărzile naționale române din Arad, 1918, Cluj-Napoca, Dacia, 1993, p. 113).

E de remarcat cât de repede și cât de promt receptează Vasile Goldiș ideile wilsoniene, cât de repede și cât de promt știe să le prindă esența înnoitoare, să le folosească în lămurirea problemelor litigioase cu maghiarii. Este cunoscut faptul că dintre toți fruntaşii politici români el avea cunoștințele filosofice și sociologice cele mai temeinice, că nu de puțin ori, punctele sale de vedere se sprijineau pe o seamă de gânditori și sociologi europeni, ale căror lucrări le citează nu de puține ori. Ideile despre națiune și naționalitate, despre libertatea şi drepturile popoarelor, despre autodeterminare, se constituie în cazul său într-un ansamblu de reguli, teorii, directive, care pot călăuzi paşii oamenilor politici atunci când sunt chemați să hotărască în numele națiunilor şi popoarelor lor, în aşa fel ca să nu se mai facă greșeli și să nu existe interpretări ambigui.

Cartea citată adună sub aceleași coperți cele mai multe dintre documentele esențiale pe care le-au elaborat în 1918 gândirea politică wilsoniană stâd la baza argumentelor folosite de îndrumătorii noștri politici. Trimiterea la ideile lui Wilson figurează și în cuprinsul celui dintâi manifest Către națiunea română, elaborat la Arad la 20 octombrie/ 2 noiembrie 1918, în care se spunea: „Fraţi şi soldați români fiți cu răbdare! Fiți cu atragere și iubire către neamul vostru, care în zilele acestea a întrat în rândul națiunilor libere, fiți mari la suflet în ceasurile acestea grele ale anarhiei și vă arătați demni de încrederea și sprijinul anticipat de națiunile mari culte, fiți demni de iubirea dezinteresată a celui mai mare om de astzi, al președintelui republicii americane, Wilson, care ca al doilea Mesia, a dus la învingere ideea că fiecare popor şi fiecare individ să fie îndreptățit și stăpân per soarta sa.” (Ibidem, p. 127). Acest titlu de ,al doilea Mesia" este preluat și de ziarul „Renașterea română” care anunță încă de la 3 noiembrie dorinţa șirienilor de a se uni cu frații lor din România, în așa fel încât ,să fie demi de încredere ca în ziua care ne recâștigă libertatea” să păstrăm „ordinea cea mai exemplară"(Ibidem, p. 171). Referirea la principiile de adevăr şi respect reciproc proclamate de Wilson sunt făcute și în Nota ultimativă trimisă de CNRC către Comitetul Național maghiar la 9 noiembrie 1918, pentru a accepta ca românii aflați în satele controlate de ei să li se acorde dreptul „la împreună lucrare cu autorităţile publice” și ,exercitar e dreptului de liberă dispoziţiune asupra sorții noastre”, mod de comortament civilizat „față $\mathrm{cu}$ toate celelalte popoare aflătoare pe teritoriul de sub întrebare / în sensul/ că vom respecta din partea noastră principiile lui Wilson" (Ibidem, p.177).

Interesul şi îngrijorarea cu care presa maghiară urmărește evenimentele și declarațiile cele mai recente ale lui Wilson se certifică și în comentariul poziției românești pe care încearcă s-o descifreze dr. Varjassy, primarul maghiar al Aradului, într-o intervenţie din „Aradi Hirlap” din 10 noiembrie 1918, făcând reeferire la răspunsul 
pe care Wilson l-a dat reprezentantului român laWashington, potrivit căreia „România are pretenții la teritoriile de limbă română din Ungaria, care potrivit constatării noastre se întind până la Chitighaz." Precizând în mod obiectiv faptul potrivit căruia „Comitetul care reprezintă cauza națiunii române din Ungaria, după cum se știe a decis deja că soarta românilor din Ardeal și în general din Ungaria să o decidă numai adunarea naţională". Reluându-și declarația, el avea să precizeze că „,ideile și străduințele națiunii române din Ungaria care s-au ridicat în legătură cu pacea bazată pe punctele wilsoniene, nimeni nu poate să aibă dubii că administrația județului trebuie să ajungă în mâna românilor" (Ibidem, p. 182). Nu peste multă vreme au avut loc la Arad tratativele cu trimișii guvernului de la Budapseta în frunte cu Jaszi Oszkar, iar Goldiş chestionat în legătură cu granițele viitorului stat român, a făcut următoarele precizări la 1o noiembrie 1918: „Principiile lui Wilson trebuie să se realizeze. Tot ce-i deo limbă trebuie să fie la un loc. De aceea nota lui Wilson o înțeleg așa că Ardealul se desface de Ungaria. E şi lucru firesc, câtă vreme românii sunt în majoritate în Ardeal. Au trecut vremurile când minoritatea a putut stăpâni mase mari de popoare. Câteva sute de oameni cu privilegii au expropriat în Ungaria drepturile milioanelor. S-au schimbat lucrurile. De aici înainte marea majoritate a poporului se va guverna pe sine și pe minoritatea cu care conviețuiește. Așa e logic şi just. Pământul unde locuiesc românii în majoritate e pământ românesc şi fiindcă Ardealul e astfel de teritor, e firesc să apară României, dar nu numai Ardealul ci şi toate teritoriile Ungariei unde românii sunt în majoritate.” Și mai departe: „Națiunile vor trăi și lucra ca indivizi ai unui stat uriaș și precum azi libertatea singuratecilor cetățeni e prețioasă, în urma cătușelor stânjenitoare ce și le-au pus ei înșişi, astfel în marele stat universal, singuratecele naţiuni vor fi atari indivizi, care sunt datori să viețuiască după legile marii comunități a națiunilor. Acest fapt va fi începutul păcii veșnice. Conferința de pace are menirea să creeze această ordine ideală pe pământ.” (Ibid., p. 186-187).

Cuvinte mai frumoase despre modul în care V.Goldiș gândea lumea viitoare nu pot fi întâlnite la altcineva din anturajul său din acel moment. Doctrinarul ideii naţionale și arhitectul unirii de la Alba Iulia are chiar o credință puțin prea idealistă atunci când crede că pe viitor nu vor mai avea loc fricțiuni, și crede apoi că și cei din comisia de pace vor da românilor toate teritoriile în care li se vorbea limba, ceea ce nu s-a întâmplat. O altă notă din „Românul”, din 1o noiembrie 1918, sublinia că privitor la administrație lucrurile se vor schimba pe viitor prin resppectarea principiilor wilsoniene: „Oricum se vor realiza aspirațiunile națiunei române din Ungaria la pacea, ce se va face pe baza punctelor lui Wilson, nu mai poate fi nicio îndoială că administrația comitatului va trebui să treacă în mâinile românilor." (Ibid., p.188).

Ideile wilsoniene vor deveni de acum înainte un bun comun pentru toți actanţii români care vor conduce în acel moment destinele poporului român. Este astfel de salutat că unul dintre manifestele emanate de comandantul gărzilor române din Arad, preotul Vasile Debu, începe atât de strălucit și de înălțător cu aluzia la marile schimbări conceptuale aduse de cele mai nnoi idei înaintate ale veacului. Iată dovada: „Frați preoți! Ceasul reînvierii neeamului a sunat. Zorile mândre se refectă măreț pe întreg orizontul neamului românesc. Solia îmbucurătoare triisă de președintele Statelor Unite, Wilson, prin care se reccunosc toate aspirațiile noastre ca popor liber şi independent, a umplut de firească bucurie orice inimă românească. Lanțurile grele, cu care asupritorii de veacuri au încătușat mîinile și picioarele noastre, au căzut suvraja înțeleptelor vorbe alelui Wilson, căruia toată lumea, dar mai ales noi românii, îi trimitem omagii de sinceră mulţuită și recunoştință."(Ibidem, p. 198). Aceste idei novatoare au condus hotărârile delegației 
române și la întâlnirea cu delegația maghiară condusă de Jaszi la Arad, când guvernul maghiar a încercat o ultimă stragemă de lămurire a românilor de a rîmâne într-o federație cu maghiarii. Or, comunicatul elaborat de grupul de români prezenți la tratative a fost deosebit de tranşant şi lipsit de echivoc, afirmând: „Naţiunea română recunoaște competența congresului de pace la fixarea limitelor definitive ale teritoriilor reclamate de această națiue pentru statul său propriu, precum ia asupra sa obligamentul că față de celelalte popoare locuitoare pe acest teritor va respecta principiile wilsoniene și e gata să asigure pentru fiecare popor condițiunile liberei dezvoltări naționale." (Ibid., p.212). Toate manifestele și apelurile noilor orgaanisme de conduccre înființate de români se vor sprijini pe acest tip de declarații, protestând, de exemplu, împotriva acuzaţiei de antisemitism, aruncată în spațiul public de „Aradi Hirlap”, când Iuliu Maniu, Șt.Cicio Pop, și V.Goldiș ies public cu o replică de mare efact, declarând cu temeinicie: „Noi îi considerăm pe evrei la fel de frați, ca pe toate celelalte popoare civilizate.de altfel, noi dezaprobăm orice declarație care ar ațața sau ar inteți scânteeia urii confesionale sau naționale."(Ibid., p. 245). Același lucru îl confirmă şi aserţiunile lor privitoare la maghiari:: „Românii nu trebuie să respingă din această cauză comunitatea cu ungurii, deoarece ea nu poate fi în nici un fel dăunătoare naționalismului nostru. Noi nici nu vrem ca ungurii să se transforme în români, iar de un proces invers nu trebuie să ne fie teamă, românii nu vor deveni niciodată unguri. Românii și-au putut păstra ființa națională secole de-a rândul și în timpurile când ei erau împiedecaţi să și-o afirme. De aceea nu ne este teamă că ei ar putea, de acum înainte, ca să devină unguri." (Ibid., p.248). $\mathrm{Cu}$ noi precizări vine Vasile Goldiș în manifestul aresat confraților maghiari la 20 noiembrie 1918, prin intermediul ziarului arădan „Aradi Hirlap”, când respinge şovinismul deopotrivă cu imperialismul, specificând: „Eu găsesc cât se poate de natural ca un popor plin de demnitate să nu mai vrea să sufere robia - cum noi (ungurii -n.n.) nu am tolera-o față de Austria. Întreaga mea convinngere sociologică s-ar revolta la gândul că vreuna din naționalități să trăiască în dependență și servitute față de Ungaria." (Ibid., p. 278).

După cum se poate vedea, fondul doctrinar al ideilor wilsoniene poate fi resimţit peste tot în țesătura intimă a frazelor și a modului de a gândi al fruntaşilor politici români. Wilson i-a ajutat să se regăsească pe sine şi să-şi înţeleagă mai bine rostul şi menirea în spaţiul național în care s-au manifestat de veacuri. E un moment de cotitură pe care abia acum a putut fi exprimat cum trebuie, la înalții parametri ai gândirii liberale moderne. Aportul doctrinar wilsonian a contribuit din plin la clarificarea pozițiilor și atitudinilor elitelor românești conducătoare, la aşezarea lor de partea progresului și a toleranței și respectului reciproc, la fundamentarea unei concepții moderne, înaintate, despre rolul statului şi al administrației în viața popoarelor. Or, V. Goldiș şi companionii săi au dovedit, odată în plus, că au fost la înălţimea cerințelor momentului istoric pe care l-au traversat.

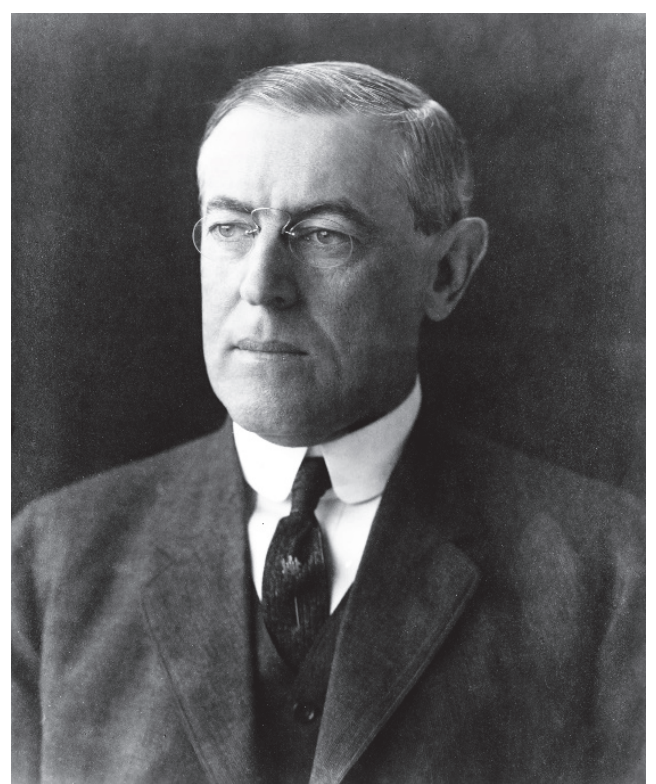

